\title{
The Blue Pigment and Mucilage of Schizophyllum commune
}

\author{
Sei Tachibana ANd JiUichi Siode ${ }^{2}$ \\ Department of Chemistry, Faculty of Science and Engineering, \\ Ritsumeikan University, Kita-ku, Kyoto (Post No.603)
}

(Received May 30, 1968)

\begin{abstract}
During the $\mathrm{L}^{-}$-malate production through $\mathrm{CO}_{2}$-fixing process by Schizophyllum commune, a blue coloration was seldom seen. When the coloration occurred within 6 days after inoculation, the malate production was markedly reduced, and at the same time the sugar consumption was somewhate lowered. The more earlier the coloration occurred, the more marked was the decrease of L-malate produciton. The addition of thiamine, lipoic acid and pantothenic acid caused the stimulation of sugar utilization and the inhibition of malate production, but the blue coloration caused the lowering of the former and the enhancing of the latter. The inhibitory effect of $\mathrm{Cu}^{2+}$ on the malate production was not affected by the blue pigmentation.

The addition of an ethanolic extract of the blue mycelia caused marked decrease of malate production. When the ethanolic extract was converted to a brown red substance during evaporation of ethanol, such effect of addition was not observed.

The blue pigment may promote the reverse reaction of phosphoenolpyruvate carboxylation.

When mucilage was produced in the medium, an increase of L-malate production was observed.
\end{abstract}

The first indication of an occurrence of L-malate in the cultured medium of Schizophyllum commune was the report by Sei Tachibana of a study on the $\mathrm{CO}_{2}$ fixing fermentation (1). Following the initial discovery, extensive studies of the L-malate production through $\mathrm{CO}_{2}$-fixing process were carried out, and new procedures of the fermentation were developed in his own laboratory (1-14). By employing the mold, we have succeeded in manufacturing L-malic acid in a high yield (up to

\footnotetext{
${ }^{1}$ Studies on $\mathrm{CO}_{2}$-Fixing Fermentation XII. This paper was reported at Annual Meeting of The Society of Fermentation Technology, Osaka, November 1964; J. Ferment. Technol. 42, 704 (1964). This work was supported by the grant (No. 58135, 1963) for scientific research from Ministry of Education. Following abbreviation are used: PEP, phosphoenolpyruvic acid; $\mathrm{Pi}$, orthophosphate; OAA, oxaloacetic acid; $\mathrm{PPi}$, inorganic pyrophosphate; GAP, glyceraldehyde-3-phosphate; 1,3-DPGA, 1,3-diphosphoglycerate.

2 立花 精, 塩出十一
} 
$90 \%$ of the glucose consumed) accompanied with fumaric and succinic acids in a yield source in of about $20 \%$ of the L-malic acid using calcium carbonate as a part of the carbon source in the growing culture.

During these investigations, a blue coloration of mycelium was seldom seen in shaking culture, while the pigments were produced usually in surface culture. When the blue pigment was formed, L-malic acid production was markedly reduced.

On the other hand, mucilage was produced in both of surface and shaking culture media, and at the same time L-malate production was enhanced.

This paper describes the evidence for the relationship between the L-malate production and the coloration or the mucilage. Furthermore, some details on the properties of the blue pigment and the mucilage will be shown, and their roles on the $\mathrm{CO}_{2}$-fixing fermentation will be discussed.

\section{Materiales ANd Methods}

\section{Microorganism}

Schizophyllum commune Fries IFO 4928 was used in this work. This Basidiomycete was revealed to form L-malate mainly through reductive carboxylation of phosphoenolpyruvate linked with glyceraldehyde dehydrogenase $(12,14)$.

The stock culture of the strain was maintained on the slant of malt extract agar, or of synthetic medium composed of glucose $3 \mathrm{~g}$, peptone $0.2 \mathrm{~g}, \mathrm{NH}_{4} \mathrm{NO}_{3} 0.1 \mathrm{~g}$, $\mathrm{KH}_{2} \mathrm{PO}_{4} 0.1 \mathrm{~g}, \mathrm{MgSO}_{4} \cdot 7 \mathrm{H}_{2} \mathrm{O} 0.05 \mathrm{~g}, \mathrm{KCl} 0.05 \mathrm{~g}$, agar $1.5 \mathrm{~g}$ and tap water $100 \mathrm{ml}$.

\section{Preparation of Seed Culture}

As previously reported (2), the mold was grown in a solid culture consisting of wheat bran, pin wood-powder and water $(1: 1: 2)$ for about two weeks at $30^{\circ}$.

\section{Fermentation Procedure}

Sixty milliliters of basal medium composed of glucose $5 \mathrm{~g}, \mathrm{NH}_{4} \mathrm{NO}_{3} 0.1 \mathrm{~g}, \mathrm{KH}_{2} \mathrm{PO}_{4}$ $0.1 \mathrm{~g}, \mathrm{MgSO}_{4} \cdot 7 \mathrm{H}_{2} \mathrm{O} 0.05 \mathrm{~g}, \mathrm{KCl} 0.05 \mathrm{~g}, \mathrm{MnSO}_{4} 10^{-5} \mathrm{M}, \mathrm{CaCO}_{3} 5 \mathrm{~g}$, tap water $100 \mathrm{ml}$ per $500 \mathrm{ml}$ shaking flask was inoculated with $0.3 \mathrm{~g}$ of the solid culture, and then cultured in a reciplocated incubator shaker at $28^{\circ}-30^{\circ}$. When a seed was from the slant culture, the addition of thiamine $(0.5 \mu \mathrm{g} / 100 \mathrm{ml})$ to the basal medium was necessary.

\section{Analysis}

L-Malic acid was determined by the malic enzyme of Lactobacillus arabinosus using Warburg manometer (15). Pyruvic acid was colorimetorically measured according to Friedemann and Haugen (16). Residual glucose was determined by the modified method of Bertrand (17). To estimate the blue pigment Hitachi spectrophotometer was used.

\section{Results}

\section{Blue Coloration and L-Malate Production}

The numbers of blue mycelium-flasks were not more than a few per cent among nearly one thousand cultured flasks. When all the instances of blue coloration with their controls were picked up and listed in order of rapidity of the coloration as shown in Table 1, some correlation between the coloration time and L-malate 
TABLE 1

Relationship between the blue coloration and the L-malate production of Schizophyllum commune IFO 4928

\begin{tabular}{|c|c|c|c|c|c|c|c|}
\hline $\begin{array}{l}\text { Experiment } \\
\text { No. }\end{array}$ & $\begin{array}{l}\text { Days, blue } \\
\text { appeared }\end{array}$ & $\begin{array}{l}\text { L-Malic } \\
\text { acid }\end{array}$ & $\begin{array}{l}\text { Glucose } \\
\text { consumed }\end{array}$ & Yield & Inhibition & $\begin{array}{l}\text { Pyruvic } \\
\text { acid }\end{array}$ & Yield \\
\hline 1 & $\begin{array}{ll}- & \text { None } \\
2 & \text { Blue } \\
3 & \text { Blue }\end{array}$ & $\begin{array}{c}m g / 100 m l \\
2,480 \\
204 \\
972\end{array}$ & $\begin{array}{c}m \mathrm{~m} / 100 \mathrm{ml} \\
4,421 \\
4,075 \\
4,692\end{array}$ & $\begin{array}{c}\text { per cent } \\
56.2 \\
5.0 \\
20.8\end{array}$ & $\begin{array}{l}\text { per cent } \\
\\
\quad 91.2 \\
63\end{array}$ & $\mathrm{mg} / 100 \mathrm{ml}$ & per cent \\
\hline 2 & $\begin{array}{l}- \text { None } \\
3 \text { Blue } \\
3 \text { Blue }\end{array}$ & $\begin{array}{r}2,320 \\
803 \\
518\end{array}$ & $\begin{array}{l}4,826 \\
4,780 \\
4,631\end{array}$ & $\begin{array}{l}48.1 \\
16.8 \\
11.2\end{array}$ & $\begin{array}{l}65 \\
76.8\end{array}$ & & \\
\hline 3 & $\begin{array}{l}\text { None } \\
4 \text { Blue }\end{array}$ & $\begin{array}{l}3,595 \\
2,095\end{array}$ & $\begin{array}{l}4,754 \\
4,420\end{array}$ & $\begin{array}{l}75.8 \\
47.4\end{array}$ & 37.5 & $\begin{array}{l}44 \\
74\end{array}$ & $\begin{array}{l}0.93 \\
1.68\end{array}$ \\
\hline $4^{a}$ & 4 None & $\begin{array}{l}2,470 \\
1,500\end{array}$ & $\begin{array}{l}3,516 \\
3,470\end{array}$ & $\begin{array}{l}70.3 \\
43.2\end{array}$ & 38.5 & & \\
\hline $5^{b}$ & 4 Blue & $\begin{array}{r}12,985 \\
7,250\end{array}$ & $\begin{array}{l}14,631 \\
14,627\end{array}$ & $\begin{array}{l}88.7 \\
49.6\end{array}$ & 44 & & \\
\hline 6 & $\begin{array}{l}\text { - None } \\
5 \text { Blue }\end{array}$ & $\begin{array}{l}3,610 \\
2,435\end{array}$ & $\begin{array}{l}4,505 \\
4,483\end{array}$ & $\begin{array}{l}80.2 \\
54.3\end{array}$ & 32.5 & $\begin{array}{r}17 \\
191\end{array}$ & $\begin{array}{l}0.34 \\
4.26\end{array}$ \\
\hline 7 & $\begin{array}{l}\text { - None } \\
5 \text { Blue }\end{array}$ & $\begin{array}{l}3,350 \\
2,315\end{array}$ & $\begin{array}{l}4,653 \\
4,525\end{array}$ & $\begin{array}{l}72.1 \\
51.2\end{array}$ & 29.5 & $\begin{array}{l}46 \\
40\end{array}$ & $\begin{array}{l}0.99 \\
0.89\end{array}$ \\
\hline 8 & - 5 Blue & $\begin{array}{l}2,975 \\
1,810\end{array}$ & $\begin{array}{l}4,420 \\
4,140\end{array}$ & $\begin{array}{l}67.3 \\
43.8\end{array}$ & 35 & & \\
\hline 9 & $\begin{array}{l}\text { None } \\
5 \text { Blue }\end{array}$ & $\begin{array}{l}3,770 \\
2,125\end{array}$ & $\begin{array}{l}5,000 \\
4,095\end{array}$ & $\begin{array}{l}75.4 \\
52.0\end{array}$ & 31 & & \\
\hline 10 & -6 None & $\begin{array}{l}3,500 \\
3,350\end{array}$ & $\begin{array}{l}4,872 \\
4,894\end{array}$ & $\begin{array}{l}71.9 \\
68.5\end{array}$ & 4.5 & & \\
\hline 11 & - 6 None & $\begin{array}{l}2,505 \\
1,578\end{array}$ & $\begin{array}{l}4,303 \\
3,089\end{array}$ & $\begin{array}{l}58.2 \\
51.1\end{array}$ & 12 & & \\
\hline 12 & $-\begin{array}{l}\text { None } \\
6 \text { Blue }\end{array}$ & $\begin{array}{l}2,775 \\
2,705\end{array}$ & $\begin{array}{l}4,780 \\
4,802\end{array}$ & $\begin{array}{l}58.0 \\
56.4\end{array}$ & 2.8 & $\begin{array}{l}175 \\
152\end{array}$ & $\begin{array}{l}3.66 \\
3.14\end{array}$ \\
\hline 13 & $\begin{array}{r}\text { None } \\
10 \text { Blue }\end{array}$ & $\begin{array}{l}3,410 \\
3,500\end{array}$ & $\begin{array}{l}4,582 \\
4,547\end{array}$ & $\begin{array}{l}74.5 \\
77.0\end{array}$ & & $\begin{array}{l}48 \\
26\end{array}$ & $\begin{array}{l}1.05 \\
0.57\end{array}$ \\
\hline 14 & - $\begin{array}{l}\text { None } \\
\text { Blue }\end{array}$ & $\begin{array}{l}3,615 \\
3,782\end{array}$ & $\begin{array}{l}4,849 \\
4,802\end{array}$ & $\begin{array}{l}74.6 \\
78.8\end{array}$ & & $\begin{array}{l}19 \\
10\end{array}$ & $\begin{array}{l}0.39 \\
0.28\end{array}$ \\
\hline
\end{tabular}

$a$ No. 4 Glucose $3.6 \mathrm{~g} / 100 \mathrm{ml}, \mathrm{CaCO}_{3} 6 \mathrm{~g} / 100 \mathrm{ml}$

$b$ No. 5 Glucose $15 \mathrm{~g} / 100 \mathrm{ml}, \mathrm{CaCO}_{3} 15 \mathrm{~g} / 100 \mathrm{ml}$

production seems to be existent. In these experiments $3.6,5$ and $15 \%$ glucose media were analyzed after 7,10 and 16 day cultures, respectively. The occurrence of coloration seemed to be spontaneous, since the time of coloration was not fixed. The frequency of coloration was raised in 4-6 day culture. Whenever the coloration occurred within 6 days, L-malate production was inhibited without any exception. At all events, it was shown that the earlier the pigment was formed, the more marked was the decrease of malate production. Such correlation was not observed both in the experiment No. 13 and No. 14, in which blue colorations appeared within 12 hours before analysis of the 10 day culture. In these two cases, the malate productions of blue mycelia were not diminished. Therefore, it was suggested that the decrease of malate production did not cause the coloration of 
the mycelium, but the latter might cause the former.

This suggestion would be supported by other experiments as follows. As shown in Fig. 1, when the normal type mycelia of 16 day culture in stationary flask was halved, and each of them was used as the seed for two shaking cultures as mentioned above, a blue coloration occurred in one of them on the 2nd day of culture. Before the coloration, the amount of L-malic acid produced in the colored flask was larger than that of the other normal colorless flask. But after the coloration, the malate production of the blue one began to decrease more than that of the normal one, reaching to about a half of that of the normal one in the 7th day culture. Moreover, after the coloration, the amount of residual glucose of the blue one was larger than that of the normal one. Accordingly, it is considerable that the blue coloration may inhibit the accumulation of malate.

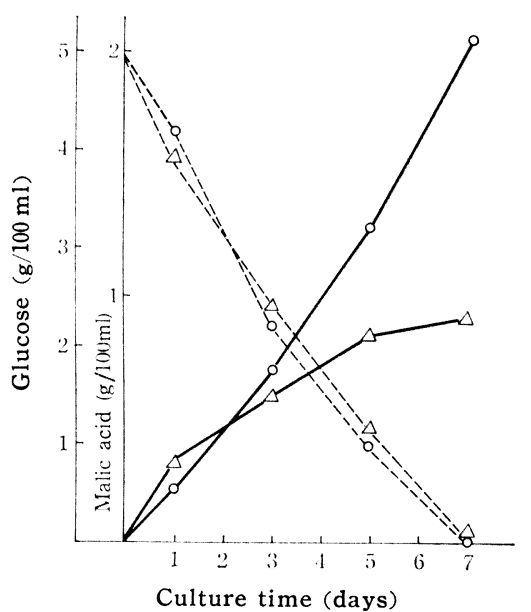

FIG. 1 Time Courses of L-Malic Acid Fermentations by Normal and Blue Types of Schizophyllum com. mune

-, L-malic acid; $\cdots$, residual glucose; $O$, normal type; $\triangle$, blue type.

Meanwhile, the coloration seemed to be inhibited by malonate, because even when the coloration occurred in 3 per 7 flasks of control (exceptionally high rate), no coloration occurred in all 7 flasks containing $0.1 \%$ malonate. The amount of malate of the malonate-containing flask was larger not only than the blue one, but also than the white normal one. It was of interest that malonate was simultaneously effective both on the promotion of malate production and on the protection from the coloration.

\section{Vitamins and Coloration}

As previously reported, the additions of each $0.1 \mathrm{mg}$ of thiamine, lipoic acid and pantothenic acid in $100 \mathrm{ml}$ culture medium caused the remarkable decrease of malate

TABLE 2

Influence of the Blue Coloration on the Effects of the additions of Thiamine, Lipoic Acid and Pantothenic Acid in the Growing Culture of Schizophyllum commune

\begin{tabular}{|c|c|c|c|c|c|c|c|c|}
\hline $\begin{array}{l}\text { Experiment } \\
\text { No. }\end{array}$ & $\mathrm{OAR}^{a}$ & $\begin{array}{l}\text { Culture } \\
\text { time }\end{array}$ & $\begin{array}{c}\text { Thiamine } \\
\text { Lipoic acid } \\
\text { Pantothenic } \\
\text { acid }\end{array}$ & $\underset{\text { pigment }}{\text { Blue }}$ & $\underset{\text { acid }}{\mathrm{L}-\mathrm{Malic}}$ & $\begin{array}{l}\text { Glucose } \\
\text { consumed }\end{array}$ & Yield & Inhibition \\
\hline \multicolumn{2}{|c|}{$m M \mathrm{O}_{2} /$ liter $/ \mathrm{min}$} & $n$ days & $1 \mathrm{mg} / 100 \mathrm{ml}$ & \multicolumn{2}{|c|}{$\mathrm{mg} / 100 \mathrm{ml}$} & $\mathrm{mg} / 100 \mathrm{ml}$ & per cent & \multirow{2}{*}{\begin{tabular}{cc}
\multicolumn{2}{c}{ per cent } \\
0 & \\
24.3 & 0 \\
76.1 & 68.2
\end{tabular}} \\
\hline 1 & 0.46 & $\begin{array}{l}8 \\
7 \\
7\end{array}$ & $\begin{array}{l}\text { No } \\
\text { Added } \\
\text { Added }\end{array}$ & $\begin{array}{l}\text { No } \\
\text { No } \\
\text { Formed }\end{array}$ & $\begin{array}{r}1,750 \\
1,471 \\
275\end{array}$ & $\begin{array}{l}4,218 \\
4,677 \\
2,740\end{array}$ & $\begin{array}{l}41.6 \\
31.5 \\
10.0\end{array}$ & \\
\hline 2 & 0.35 & $\begin{array}{l}8 \\
7 \\
7\end{array}$ & $\begin{array}{l}\text { No } \\
\text { Added } \\
\text { Added }\end{array}$ & $\begin{array}{l}\text { No } \\
\text { No } \\
\text { Formed }\end{array}$ & $\begin{array}{r}2,000 \\
968 \\
354\end{array}$ & $\begin{array}{l}3,867 \\
4,377 \\
3,638\end{array}$ & $\begin{array}{r}51.8 \\
22.1 \\
7.6\end{array}$ & $\begin{array}{cc}0 & \\
57.4 & 0 \\
85.3 & 65.6\end{array}$ \\
\hline
\end{tabular}

$a$ Oxygen absorption ratio. 
production and the distinct stimulation of glucose consumption. In some experiments, the blue colorations occurred in the flasks, containing three vitamins while no pigmentation was observed in the control flasks. In this case, as shown in Table 2, the blue pigmentation caused the strengthening of the inhibition of the malate production and the lowering of the stimulation of the glucose consumption. The activity of the blue pigment, therefore, seemed to be heterogeneous to that of these three vitamins as cofactors of pyruvate dehydrogenase complex. It was also likely that the blue pigment might not accelerate the dehydrogenation of L-malate, because the amount of pyruvate accumulated was not always increased by the blue pigmentation as shown in Table 1.

\section{3. $\mathrm{Cu}^{2+}$ and Blue Coloration}

As previously reported, the addition of $10^{-4}-10^{-3} \mathrm{M} \mathrm{CuSO}_{4}$ to the medium caused a marked inhibition of the malate production. By the addition, greenish blue coloration of the mycelium was more frequently observed, but the inhibitory effect of $\mathrm{Cu}^{2+}$ on the malate production was not affected by the coloration, as shown in Table 3. Therefore, it would be supposed that the blue pigment might be associated with $\mathrm{Cu}^{2+}$-sensitive enzyme, e.g., phosphoenolpyruvate carboxykinase.

TABLE 3

Influences of the Blue Coloration on the Effects of the Addition of $\mathrm{CuSO}_{4}$ in the Growing Culture of Schizophyllum commune

\begin{tabular}{cccccc}
\hline CuSO $_{4}$ added & Blue pigment & L-Malic acid & Glucose consumed & Yield & Inhibition \\
\hline$M$ & & $m g / 100 m l$ & $m g / 100 m l$ & per cent & per cent \\
None & No & 2,140 & 4,900 & 43.7 & \\
$10^{-4}$ & No & 1,691 & 4,900 & 34.5 & 21.0 \\
$10^{-4}$ & Formed & 1,882 & 5,000 & 37.7 & 13.7 \\
$2 \times 10^{-3}$ & No & 718 & 4,826 & 14.9 & 65.8 \\
$10^{-3}$ & Formed & 640 & 5,000 & 12.8 & 70.7 \\
\hline
\end{tabular}

\section{Effect of Addition of Pigment}

It was found that the blue pigment could be extracted by organic solvents such as chloroform, acetone, methanol, ethanol, toluene, xylene and ether. As indicated in Table 4, the addition of the ethanolic extract of the blue mycelium caused a marked decrease of the malate production and some inhibition of the glucose utilization. It was to be noted that such inhibitions were not detected,

TABLE 4

Effect of the Addition of the Blue Pigment on the L-Malic Acid Fermentation using Schizophyllum commune

\begin{tabular}{ccccc}
\hline \hline $\begin{array}{c}\text { Ethanolic extract } \\
\text { of blue mycelium }\end{array}$ & L-Malic acid & Glucose consumed & Yield & Inhibition \\
\hline$m l / 100 m l$ & $m g / 100 m l$ & $m g / 100 m l$ & per cent & per cent \\
0 & 2,322 & 5,000 & 46.5 & \\
0.2 & 288 & 4,179 & 6.9 & 85.2 \\
0.5 & 95 & 4,254 & 2.2 & 95.3 \\
\hline 0 & 2,080 & 5,000 & 41.7 & \\
$0.02(\mathrm{mg})$ & 403 & 4,568 & 8.8 & 78.9 \\
0.02 & 144 & 4,462 & 3.2 & 92.3 \\
\hline
\end{tabular}




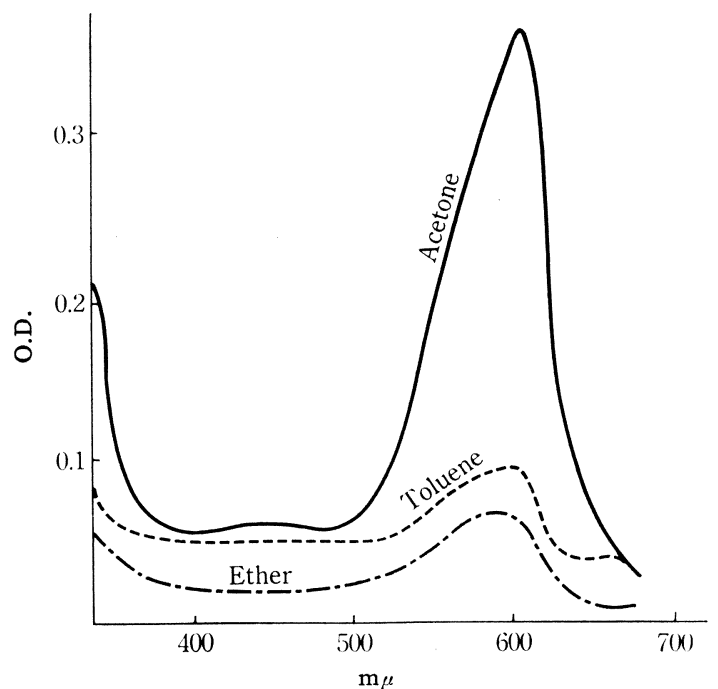

FIG. 2 Spectra of Extracts with Three Organic Solvents of Blue Mycelia of Schizophyllum commune

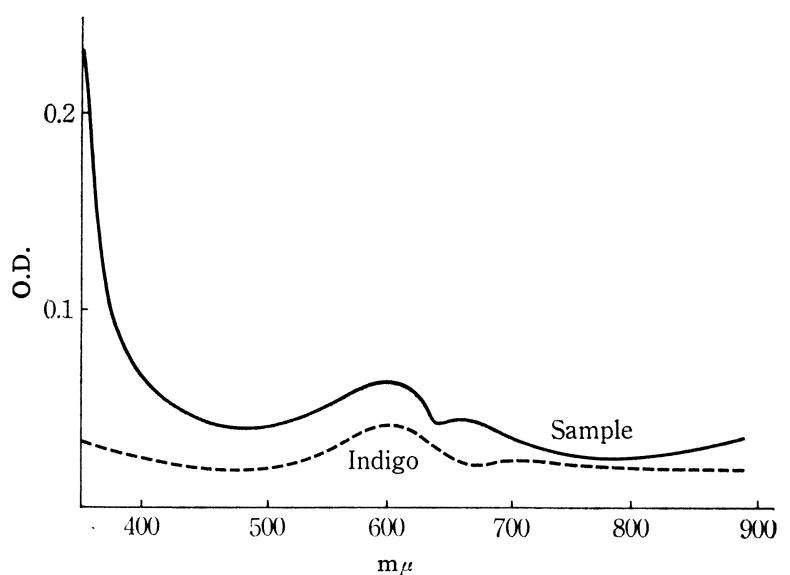

FIG. 3 Spectra of Xylene Solutions of the Blue Pigment and Indigo when the ethanolic extract was converted to brown red from blue during heating to evaporate the solvent before the addition. By the heating, it was also observed that the blue pigment was sublimed in some cases.

5. Properties of Blue Pigment

The spectra of extracts with organic solvents of the blue mycelium exhibited $\lambda_{\max }$ at 600 $\mathrm{m} \mu$ as in Fig. 2. Both spectra of the pigment and indigo blue were compared in xylene as shown in Fig. 3, where in addition to the first peak at $600 \mathrm{~m} \mu$ corresponding to that of indigo, the second peak at $670 \mathrm{~m} \mu$ and an intensive absorption in u.v. were observed in the unknown sample. The brown red product by moderate heating resembled isatin, which should be yielded upon the oxidation of $\mathrm{HNO}_{3}$ from indigo.

\section{Mucilage}

During the L-malate fermentation, mucilage was usually seen on or in the fluid of surface or submerged culture, respectively. The mucilage on the surface formed a tranparent film. The mucilage produced in the shaking culture containing initially over $10 \%$ glucose made the broth a gel state in latter period of fermentation. The speed of synthesis of the mucilage was so high that a thick film was formed over the mycelia stocked in a refrigerator overnight after harvested and washed. When a large amount of the mucilage was produced, the L-malate production was enhanced. It was assumed, therefore, that there were some relationships between the mucilage and L-malate production.

The physicochemical properties of the mucilage were investigated to some extent. The mucilage was precipitated by $45 \%$ methanol or ethanol. The precipitate was hardly redissolved in water. It was hardly hydrolyzed by mineral acid. A hydrolyzate obtained by concentrated $\mathrm{HCl}$ was detected as glucose. From these 
evidences, it seemed likely that the mucilage might be a glucan with other than $\alpha-1,4$ or $-1,6$ linkage.

\section{Discussion}

The main process of the L-malate fermentation was proposed as follows $(12,14)$. $\mathrm{PEP}+\mathrm{CO}_{2}+\mathrm{Pi} \longrightarrow \mathrm{OAA}+\mathrm{PPi}$

$\mathrm{GAP}+\mathrm{Pi}+\mathrm{NAD}+\mathrm{OAA} \longrightarrow$ 1,3-DPGA $+\mathrm{NAD}+\mathrm{L}-$ malate

Equation 1 is catalyzed by a phosphoenolpyruvate carboxytransphosphorylase-like enzyme. Equation 2 shows a malic dehydrogenase reaction coupled with glyceraldehyde dehydrogenase linked by NAD. The blue pigment would interfere with the cources of these processes.

On the other hand, it might be also likely that the blue pigment might accelerate the decarboxylation of OAA or might promote TCA cycle resulting in the same decrease of the accumulation of malate. But the promotion of TCA cycle by the blue pigment is almost unreliable, since the utilization of glucose was reduced by the coloration or by the addition of blue pigment, as indicated in Tables 1, 2 and 3 or in Fig. 1, especially in Table 2, where the three vitamins, i.e., thiamine, lipoic acid and pantothenic acid were added, and since pyruvate was much more accumulated in some cases when the coloration occurred.

If the blue pigment is indigo derivative, tryptophan may be a precursor of the pigment. Therefore, by the formation of the pigment, the amount of NAD derived from tryptophan would be decreased. The decrease of the amount of NAD would cause the inhibition of the reduction of OAA linked to glyceraldehyde dehydrogenase of Equation 2. Nevertheless, in accordance with the evidences in Table 4, it is preferable to assume for the blue pigment or its relating compound itself to inhibit the L-malate production through the course of Equation 1 or 2.

As indicated in Table 3 , the blue coloration did not affect the inhibitory effect of $\mathrm{Cu}^{2+}$ which is known as an inhibitor of phosphoenolpyruvate carboxykinase of Aspergillus niger (18). Moreover, in the cases of Fig. 1 and others, the blue coloration usually occurred when the growth of the mold was accelerated comparatively. As mentioned above, the consumption of glucose was diminished by the coloration. Consequently, it seems to be conclusive that the blue pigment or its associated substance would accelerate the reverse reaction of phosphoenolpyruvate carboxylation causing the promotion of glycogenesis or glyconeogenesis of the mold.

Miles et al. isolated indigo and indirubin-like pigment from a mutant of Schizophyllum commune, while neither L-malate nor its relation to the pigments was mentioned (19).

Indole derivatives, indigo and both of indigo green and indirubin were found in many plants and animals, e.g., human urine, respectively. Moreover, indolylacetic acid has an important physiological activity on plants, while its mechanism was not elucidated yet. Tryptophan and its derivatives have also important functions on animals. Anyhow, the blue pigment, which was assumed as indigo derivatives following the experimental results and the literature as described above, will be studied further in reference to these evidences.

The mucilage may have some physiological role on the L-malate production, because other strains, e. g., IFO 6138 which produced little amount of L-malate did 
not produce such a large amount of mucilage as IFO 4928. Moreover, eventhough IFO 4928 was used, when the mucilage was not so much, the malate production was reduced. It is suggested that the mucilage might serve to keep the cultural environment anaerobic to arrange the reductive carboxylation of phosphoenolpyruvate or pyruvate.

\section{REFERENCES}

1. Tachibana, S., J., Ferment. Technol., 39, 696 (1961).

2. Tachibana, S., and Siode, J., VIIth Intern. Congr. Microbiol. Abst., 67 (1962).

3. Tachibana, S., J. Ferment. Technol., 45, 353 (1967).

4. Tachibana, S., and Siode, J., J. Ferment. Technol., 45, 358 (1967).

5. Tachibana, S., Siode, J., and Nisiuchi, H., J. Ferment. Technol., 45, 432 (1967).

6. Tachibana, S., and Shiode, J., J. Ferment. Technol., 45, 432 (1967).

7. Tachibana, S., J. Ferment. Technol., 45, 436 (1967).

8. Tachibana, S., Siode, J., and Watase, S., J. Ferment. Technol., 45, 595 (1967).

9. Tachibana, S., and Siode, J., J. Ferment. Technol., 45, 602 (1967).

10. Tachibana, S., and Siode, J., J. Ferment. Technol., 45, 607 (1967).

11. Tachibana, S., and Yamamoto, N., J. Ferment. Technol., 45, 701 (1967).

12. Tachibana, S., Umehara, K., and Siode, J., J. Ferment. Technol., 45, 1040 (1967).

13. Tachibana, S., Yamasita, H., and Siode, J., J. Ferment. Technol., 43, 713 (1965).

14. Tachibana, S., Siode, J., and Hanai, T., J. Ferment. Technol., 45, 1130 (1967).

15. Nossal, P. M., Biochem. J., 49, 407 (1951).

16. Friedemann, T. E., and Haugen, G. E., J. Biol. Chem., 147, 415 (1943).

17. Henmi, T., and Tomoeda, M., J. Agr. Chem., 19, 381 (1943).

18. Woronick, C. L., and Johnson, M. L., J. Biol. Chem., 235, 9 (1960).

19. Miles, P. G., Lund, H., and Raper, J.R., Arch. Biochem. Biophys., 62, 1 (1956). 